\title{
Cabdrivers and Their Fares: Temporal Structures of a Linking Ecology
}

\author{
Marcin Serafin ${ }^{1,2}$
}

\begin{abstract}
The author argues that behind the apparent randomness of interactions between cabdrivers and their fares in Warsaw is a temporal structure. To capture this temporal structure, the author introduces the notion of a linking ecology. He argues that the Warsaw taxi market is a linking ecology, which is structured by religious time, state time, and family time. The author then focuses on waiting time, arguing that it too structures the interactions between cabdrivers and their fares. The author makes a processual argument that waiting time has been restructured by the postsocialist transformation, but only because this transformation has been continually encoded through the defensive and adaptive strategies of cabdrivers responding to the repetitive and unique events located across the social space. The author concludes with the claim that linking ecologies are a recurring structure of the social process and that they form the backbone of globalization, financialization, and mediatization.
\end{abstract}

\section{Keywords}

linking ecologies, processual sociology, temporal structure, taxi markets, social space

In a large city like Chicago the hiring of a cab by a passenger may be conceived of in much the same way as the random collision of particles in an atomic field. True, there are some sectors of the field in which particles come into more frequent collision than others, for example, downtown, at railroad depots, and at the larger neighborhood shopping centers. But this kind of differential activity within the field as a whole provides little basis for predicting the coupling of any two specific particles.

—Fred Davis (1959), “The Cabdriver and His Fare: Facets of a Fleeting Relationship"

\footnotetext{
'Institute of Philosophy and Sociology, Polish Academy of Sciences, Warsaw, Poland ${ }^{2}$ Max Planck Institute for the Study of Societies, Cologne, Germany

\section{Corresponding Author:}

Marcin Serafin, Institute of Philosophy and Sociology, Polish Academy of Sciences, Nowy Świat 72, Warsaw, 00-330, Poland.

Email: serafin@mpifg.de
}

\section{MPIfG Journal Article}

Marcin Serafin: Cabdrivers and Their Fares: Temporal Structures of a Linking Ecology. In: Sociological Theory 37(2), 117-141 (2019). Sage Publications 
The Chicago sociologist Fred Davis (1959) based his classic article on an assumption that is wrong. In a large city such as Chicago, the couplings of cabdrivers and their fares are not outcomes of a random process. They are outcomes of a social process. This article demonstrates why this process is not random and what is social about it.

Davis saw a nonrandom distribution of interactions in the city, but he assumed that they were the outcome of a random process. This assumption allowed Davis to focus on the logic of interaction: to study how cabdrivers classify their customers and adapt their strategies accordingly. It enabled him to avoid having to theorize the connection between the clearly visible, yet brief, interaction between cabdrivers and their fares - their "fleeting relationship"-and the less visible, yet more enduring, structure of the city. In other words, by making this assumption, Davis evaded one of the most difficult problems of sociological theory: the connection between social interaction and social structure (Liu and Emirbayer 2016).

In this article I engage with this theoretical problem that Davis assumed away and that, years later, Goffman (1983) was unable to resolve in his discussion of the interaction order. Drawing on an investigation of the Warsaw taxi market, I argue that the interactions of cabdrivers and their fares have not only a spatial structure, which Davis saw but ignored, but a temporal structure as well. This temporal structure anchors who interacts with whom, when and where, and for how long. It shapes the length of cabdrivers' working time, their incomes, and how long they spend waiting for customers. The temporal structure, I argue, is the outcome of the social process: it is the product of historical legacies, institutional rhythms, event durations, and the defensive and adaptive strategies of cabdrivers and their fares. ${ }^{1}$ To capture the temporal structure of the Warsaw taxi market, this article introduces the notion of linking ecology, which I argue is a recurring structure of the social process.

\section{PRINCIPLES OF HUMAN ECOLOGY}

I claim to provide an ecological account of the couplings of cabdrivers and their fares, so a short introduction to this approach is required. There has been much discussion of what defines human ecology (e.g., Abbott 2016; Hollingshead 1939; Liu and Emirbayer 2016; McKenzie 1968; Park 1952), but here I assume it involves three interrelated principles.

First, human ecology investigates the relationship between social actors and their cultural environment. The basic definition of ecology is "the branch of science concerned with the interrelationships of organisms with each other and with their environment" (Levin 2009:799). Borrowing a metaphor from Herbert Simon (Todd and Gigerenzer 2012:34), ecological theory assumes that to study social action, we should imagine a pair of scissors where one blade represents the structure of the task environment and the other blade the capabilities and resources of the actor performing this task (Daipha 2015:5; Hutchins 2010; Lahire 2011:xi). However, the theory also postulates that these two blades coevolve within the same social process (Abbott 2016:23-25). ${ }^{2}$

Second, human ecology is fundamentally processual. In this view, the social process is made up of events: "local consummations of action and interaction that knot the contingencies of the present into new relations and structures that become the constraints and potentialities of the next movement - its past" (Abbott 2016:1; cf. Wagner-Pacifici 2017). Social structures and personalities are "lineages of successive events" (Abbott 2016:ix). If the social world is reproduced over time, it is only because "certain parts of the past are continuously (re)encoded into the present synchronic social structures" (Abbott 2016:14). How exactly the process of encoding takes place - how in a world of perpetual movement certain things remain stable over time-is the fundamental problem of processual sociology. Processual sociology is, at its core, a theory of encoding. 
Third, human ecology is relational (Abbott 2016:33-34). It studies "the community as an organic entity in which the human elements are bound together in an intricate and ever-changing web of life" (McKenzie 1968:103). The relations weaving social actors together, in what Chicago sociologists like to call the "web of life," are both interactions and relations of dependence or symbiosis (McKenzie 1968:170; Park 1952:242-44). Thus, a cabdriver is dependent on the owner of a taxi corporation, and vice versa, even if they never interact with each other. Taxi corporations are in symbiotic relations with other taxi corporations, because of what Simmel called the "indirect conflict" of market competition (Bourdieu 2005:204-208).

What matters are the positions of actors in relation to other actors (McKenzie 1968:4). However, in line with the fundamentally processual nature of the approach, the distance between positions is theorized as the time and capital it would take to travel from one position to the other (pp. 22, 220). Thus, in the ecological approach, time is not a subordinate category to space, but rather social space and social time are elements of one and the same thing: position. Cabdrivers occupy different positions in geographic and social space. It takes time and capital (gasoline) to move from one part of the city to another, that is, to travel in geographic space. It also takes time and capital to move from one taxi corporation to another, that is, to travel in social space. Joining a more prestigious corporation in Warsaw, which charges customers a higher price and has access to valuable taxi stands, ${ }^{3}$ requires saving up for a more expensive car or buying this time through use of credit.

Actors' positions in geographic and social space structure their position-takings (Liu and Emirbayer 2016:66). Where cabdrivers will go next after dropping off customers will depend on their positions in the city, or in other words, on their positions in geographic space. But it will also depend on their taxi corporations, that is, their positions is social space. Different taxi corporations have access to different taxi stands and have customers located in different areas of the city. After dropping off customers, cabdrivers have various strategies at their disposal. Nevertheless, their positions in social and geographic space afford them opportunities and resources while also imposing constraints. Their positions in social space provide them with specific points of view on social space.

One of the most important, but not the only, relationship weaving social entities together is competition (McKenzie 1968:40). Arenas of enduring competition are called ecologies. An ecology is

a social structure that is less unified than a machine or an organism, but that is considerably more unified than is a social world made up of the autonomous, atomic beings of classical liberalism or the probabilistically interacting rational actors of microeconomics. (Abbott 2016:39)

A recent development in ecological theory is the argument that ecologies are linked to other ecologies through "avatars" and "hinges" (Abbott 2016:33-74). In this article I advance this argument about the links between ecologies, as well as other locations of social space, by introducing the notion of a linking ecology.

Human ecology theorizes the social process as an ever changing web of human experience. Because different elements of that web are reweaved at different speeds, and this process of reweaving reverberates across the web, the ecological approach must address the theoretical problem that the social process is unfolding simultaneously at different temporal and spatial scales (Serafin 2017). As the ecologist Simon Levin (1992) pointed out, "Theoretical ecology, and theoretical science more generally, relates processes that occur on different scales of space, time, and organizational complexity. Understanding patterns in 
terms of the processes that produce them is the essence of science" (p. 1944). What Levin called the "problem of pattern and scale in ecology" is central not only in the study of plant and animal ecologies but also to human ecologies. For example, one of the main problems in urban sociology is how to theorize the relationship between "the multiple layers of forces" shaping a city (Abbott 2002:37). The social process is a process of "cumulative causation" (Veblen 1898:384).

Building on the idea of cumulative causation, I argue that interactions between cabdrivers and their fares are located in a multilayered temporal architecture. The foundations of this temporal architecture are religious time and state time. Nested within them are the temporal structures of different ecologies (e.g., academic calendar, political calendar) and the schedules of various organizations within those ecologies (e.g., companies, universities, hospitals). Explaining why a particular Warsaw cabdriver picks up a particular customer at a particular point in space and time requires "zooming out" and looking at the sedimentation and drift of religious traditions. Yet it also requires "zooming in" on the postsocialist transformation and then even closer to the almost instantaneous temporality of the decisionmaking process of an individual cabdriver deciding, after having dropped off a customer, what to do next. Events are better understood when located at the intersection of the various temporal foci (Cicourel 2006).

\section{SOME PROPERTIES OF LINKING ECOLOGIES}

To explain why couplings of cabdrivers and their fares are not random events, in this article I introduce the notion of a linking ecology. If ecologies are characterized by their location in social space (Abbott 2016:39), linking ecologies are those ecologies located across other ecologies (e.g., religious, political, academic) and other less structured locations of social space. Linking ecologies are the complex structures in the web of life that weave other elements of that web together.

It is useful to distinguish the concept of linking ecology from other concepts. A linking ecology is a more complex structure than an avatar. Unlike an avatar connecting two ecologies (Abbott 2016:64), linking ecologies often connect more than two other locations of social space. The cab ecology, for example, connects businesspeople, students, politicians, doctors, tourists, family members, friends, mourners, and many others with one another. The dynamics of a linking ecology are driven by competition over this task of linking. Linking ecologies are also different from "overlapping fields" (Evans and Kay 2008), "interstitial fields" (Medvetz 2012), and "overlapping ecologies" (Liu 2017). This is because members of a linking ecology are rarely members of the spaces they link. When cabdrivers link politicians with a parliamentary vote, they do not become members of the political ecology, nor do they become members of the music ecology or the religious ecology by driving musicians or priests. A linking ecology is different from an "inter-field" (inter-champ) in which actors from various fields, equipped with different forms of capital, interact with one another (Bourdieu 2015:514-16). Eighteenth-century literary salons, Bourdieu's example of interfields, were places where writers, aristocrats, and intellectuals interacted, but there were no actors competing to link these others with one another. This competition, however, is precisely what defines the cab ecology. Taxi corporations and cabdrivers compete to connect a politician with another politician, thereby linking two actors within the political ecology. But they also compete to connect the politician with a journalist who will interview her, thus linking across ecologies, or to bring the politician home to have dinner with her family. Finally, a linking ecology is more structured than a "space between fields" (Eyal 2012). Much more than just an intermediary, the Warsaw cab ecology has the properties of a field: nomos, habitus, capitals, and illusio (Serafin 2016). 
I developed the notion of linking ecology in the process of theorizing the Warsaw taxi market. It describes, however, a type of social structure that can be found throughout the social process. Different transportation industries - trucking, airline, minibus, taxis, maritime, and parcel services - are all linking ecologies. In all these industries, actors compete to connect others. What has been termed the "financial ecology" (French, Leyshon, and Wainwright 2011:812) is also a linking ecology. The financial ecology links borrowers, lenders, insurers, investors, and others. Competition among actors in the financial ecology (e.g., banks, pension funds, hedge funds, insurance companies, brokers, traders) weaves together the housing market, the manufacturing industry, universities, states, prisons, and millions of households (Davis and Kim 2015; Van der Zwan 2014). The media ecology, as I argue in the conclusion, also is a linking ecology.

Linking ecologies differ from one another in terms of who they link and how, as well as their size, structure, rhythm, and power. They nevertheless share certain properties. Defining those properties is the main objective of a theory of linking ecologies (cf. Bourdieu 1993b).

To a greater extent than in other ecologies, the rhythm of a linking ecology comprises reverberations from events taking place outside the ecology, that is, in locations of the broader social space that it links. The 2012 UEFA European Championships, the Pope's visit to Poland, and the NATO Warsaw Summit were events that took place in different ecologies - sport, religion, and politics, respectively_but all reverberated in the Warsaw taxi market, changing the demand and supply of taxis. Similarly, the housing boom, 9/11, and the election of Barack Obama were events that reverberated in the financial ecology. Because linking ecologies are dependent on external events, if they are to be successful, actors in a linking ecology must learn to synchronize with those events.

Compared with other ecologies, events taking place within a linking ecology are also more likely to reverberate across the broader social space. Put differently, there is a feedback mechanism from a linking ecology to the locations that it links. The larger and more powerful the linking ecology, the stronger the feedback. This is perhaps best illustrated by the recent crisis that emerged in the U.S. financial ecology, which then reverberated in the different locations of global social space this ecology was linking, restructuring multiple industries and millions of households over the past decade and affecting political processes in many countries along the way (cf. Wagner-Pacifici 2017:71-76). Feedback is weaker from smaller and less powerful linking ecologies. Unlike a financial crisis, a protest by a large number of cabdrivers or minibus drivers will not reverberate for years across the social space. But it will paralyze a large city or even a country for a shorter period of time (Mutongi 2017:3; Sik 1994). Some people will miss family dinners, others their flights; still others will not get to work. These less powerful events might nevertheless have significant repercussions, given that being linked on time-neither too early nor too late-is not only a necessary condition for efficient coordination but also one of the fundamental norms of modern social life.

Linking ecologies share another common property related to their temporal dimension. In a linking ecology, speed is a source of power. Linking always takes time. Individuals and organizations have a strong interest not only in being linked on time but also in the process's taking as little time as possible. This is especially the case within a capitalist system in which "time is now a currency; it is not passed but spent" (Thompson 1967:90; see also Snyder 2016). Being able to link faster than others is thus an important structural advantage. In the sixteenth century, according to Braudel (1995), "it was worth paying even large sums of money to be able to send an order off at top speed" (pp. 355-57). In the financial ecology, companies have invested millions of dollars to increase the speed of linking by a fraction of a second, just to be faster than their competitors (MacKenzie 2016). 
In other words, what matters in a linking ecology is not only speed in an absolute sense but also speed relative to others. Dominant actors are those who-because of their location in physical space, political power, technological advantage, or economies of scale - are able to link faster than others. Put in Bourdieusian terms, in a linking ecology speed is a form of capital. Yet we know from Bourdieu that any form of capital is both a resource and a stake in struggles. When they are not waiting, cabdrivers and truck drivers are often rushed to drive faster by their corporations and by customers (Sharma 2014:62-66; Snyder 2016:123, Viscelli 2016:87-90). Similar struggles over speed were at the center of competition in sixteenth-century maritime transport (Braudel 1995:300-301), in high-frequency trading in the twenty-first century (MacKenzie 2016), and in the recent conflicts over "net neutrality." When being faster than the competition is impossible, actors can try to slow their competitors down. In their struggle against Uber, for example, licensed cabdrivers in France successfully pushed for a mandatory 15-minute delay between a customer booking using the Uber app and pickup time. Introduced in 2013, this new regulation provided taxi corporations and licensed cabdrivers with a temporal advantage, in both senses of the term, as the French high administrative court suspended the regulation in 2014 (Carnegy 2014).

Linking ecologies are not only a recurring structure in the history of social life, but they also greatly contributed to this history by providing the backbone to the extended social processes of urbanization, globalization, and financialization. The emergence of a linking ecology rearranges the topology of social space. It bridges different locations of social space and brings them closer together, transforming numerous social structures in the process. The development of the cab ecology, for instance, was an important force behind urbanization. The introduction of horse-drawn cabs and omnibuses

impelled a concentration and circulation of capital, provided the easy movement throughout the city that was of special benefit to the well-to-do and tourists; spawned modern capitalist management practices and were a vital agency in the creation of the seductive and enchanting capital city of the bourgeoisie. (Papayanis 1996:171)

Similarly, the maritime ecology has been the "backbone of globalization" (Bretagnolle 2015:32; Erikson and Bearman 2006). As Bretagnolle (2015) pointed out, globalization was advanced beginning in the fourteenth century by the coevolution of the maritime ecology with the various cities it was linking. Globalization sped up in the second half of the twentieth century after the introduction of shipping containers in maritime ecology. The process of containerization, coupled with the political process of economic deregulation, doubled the number of transported goods and the speed at which they circulated, while reducing energy consumption by 90 percent. Together, containerization and deregulation restructured the positions of cities, transformed multiple industries, and changed consumption patterns almost everywhere. Although maritime ecology has recently lost some of its power, this linking ecology is still responsible for the carriage of about 90 percent of world trade (Bretagnolle 2015:32). Finally, the dynamic development of the financial ecology over the past 30 years has formed the backbone of financialization. Financialization-a social process comprising a number of subprocesses such as credit boom, securitization, financial deregulation, and the rise of shareholder value ideology (Davis and Kim 2015; Van der Zwan 2014) - has increasingly woven various locations in social space together, introducing the logic and rhythm of finance into them.

Because they are located across social space, linking ecologies provide a good vantage point to investigate the temporal order of social life. Taxi ecologies, as I will argue, show the enduring impact of religious time, state time, and family time in a capitalist society. In 
contrast, the financial ecology shows how the temporal order of financial capitalism has been transforming the family, the state, and perhaps even religion. As a 2007 Financial Times advertising campaign put it, "We Live in Financial Times" (French et al. 2011:798). We live in financial times not only because we live in an era of finance but also because the rhythm of the financial ecology increasingly shapes the rhythms of other sectors of the economy, politics, media, and family life (Halawa 2015). The recent financial crises showed this all too well.

To summarize, linking ecologies are recurring and significant structures of the social process. Studying linking ecologies requires putting their temporal dimension at the forefront of analysis. Such analysis will contribute to our understanding of other ecologies as well. Although this is often neglected, all ecologies have a temporal structure. ${ }^{4}$ And their temporal structure is likely maintained with the help of a linking ecology.

\section{DATA AND METHODS}

If you are interested in developing an ecological and processual approach in sociology, it would be difficult to find a better empirical case than cab ecologies. Park (1915) might have been aware of this when he wrote that cabdrivers "would be interesting to study" ( $p$. 586). Lefebvre surely was aware of this, because he worked as a cabdriver in Paris for two years and then devoted much of his life to theorizing the social production of space and developing a science called rhythmanalysis focused on time (Anderson 2004:28; Snyder 2016:12-15).

In this article I investigate the cab ecology in Warsaw, Poland. Fieldwork was conducted primarily between November 2012 and June 2013. At this time, the first smartphone taxi applications (iTaxi, mytaxi) had just been introduced but were not a significant element of the market. Fieldwork consisted of historical analysis; ethnographic observation; semistructured interviews with cabdrivers, family members, labor union leaders, a corporate owner, and a regulator; informal conversations with cabdrivers; analysis of Internet forums for cabdrivers and cabdriver Web sites; and a nonrepresentative survey of 246 cabdrivers conducted at different taxi stands and using an online survey.

I conducted 20 extended semistructured interviews with cabdrivers. These interviews were all recorded and lasted 1.5 hours, on average, but sometimes lasted up to 3 hours. As well as qualitative interviews and observations, together with four research assistants, we conducted a survey among 246 licensed cabdrivers. The survey provided information about working practices, work experience, attitudes toward work, family life, political engagement, income, and socioeconomic background. We distributed the 105-question survey by approaching cabdrivers on the streets (206 cabdrivers), usually at taxi stands, and using an online survey (40 drivers). The way the survey was conducted means that the sample is not representative, but it did locate the case studies of interviewed cabdrivers in a broader universe of existing cases. Thus, even though the questionnaire was an excellent source of information, I have been careful not to use it for anything other than descriptive purposes.

\section{THE GENESIS AND STRUCTURE OF CAB ECOLOGIES}

The development of cab ecologies is related to the growth of cities. Starting in the seventeenth century, cities began to grow to such an extent that it became difficult to walk between different locations. Horse-drawn cabs provided a service that was faster and more mobile than other forms of transportation. Cabs were also used as a status symbol by those who were unable to afford their own vehicles but wanted to emulate the upper classes and 
distinguish themselves from poorer people using more public means of transportation (Papayanis 1996:8-12).

$\mathrm{Cab}$ ecologies everywhere are solutions to the same problem of transporting people from point $\mathrm{A}$ to point $\mathrm{B}$, but the way this problem has been solved has varied across time and space. ${ }^{5} \mathrm{Cab}$ ecologies have been transformed by political struggles and technological innovations, including invention of the taxi meter, the car, the phone, two-way radio dispatch systems, the mobile phone, and the smartphone. These technological innovations have affected cab ecologies in different ways, as market regulations are outcomes of political contestation (Darbéra 2010b; Mathew 2008; Occhiuto 2017; Serafin 2016). We continue to find a diversity of regulations - in terms of pricing, licensing, and ownership of carsbetween different countries and sometimes even within countries (OECD 2007).

A cab ecology is structured not only by a legal framework but also by the "cake of custom" (Park 1952:226). In many cities, cabdrivers often are immigrants and ethnic minorities (New York, Stockholm), but this is not always the case (Warsaw). ${ }^{6}$ Not entirely unrelated to this, being a licensed cabdriver in London is a more prestigious job than in many other cities. Customer routines also differ among cities (Darbéra 2010a). In New York, people often hail cabs; in Lisbon, customers typically go to taxi stands; and in Warsaw, taxis are primarily ordered over the phone. On Friday evenings, the demand for taxis in Warsaw is high, as people use them to get home from work or to go to parties, compared with Jerusalem, where there is a lack of demand for and supply of taxis because of Shabbat.

\section{A LINKING ECOLOGY AND THE TEMPORAL ARCHITECTURE OF WARSAW}

The Warsaw cab ecology emerged at the end of the eighteenth century. Between 1847 and 1900, Warsaw grew from 167,000 inhabitants to more than 700,000. During this time, the number of horse-drawn cabs increased from 332 to 3,509 (Kotańska 1996). Since then, the Warsaw cab ecology has been transformed by demographic changes, urbanization, war, technological innovation, struggles over regulation, and the rise and fall of the socialist regime.

The Warsaw taxi ecology has the four basic properties of complex structures (Page 2015:24-25). First, there is a diversity of actors: about 30 taxi corporations of different sizes, three labor unions and several less institutionalized groups, about 10,000 licensed cabdrivers, a few thousand nonlicensed drivers, owners of taxi corporations, and taxi dispatchers. Second, these actors interact in the context of a structure comprising market regulation, customs, and customers' habits. Third, there is an interdependency of action. Taxi corporations compete over cabdrivers and over corporate customers; cabdrivers compete over clients and to work for certain taxi corporations. Taxi dispatchers are not in direct competition with others, but their work enables cabdrivers and taxi corporations to compete. ${ }^{7}$ Finally, actors adapt. They adapt by learning the rules of the game, but also by struggling over the rules of the game (Serafin 2016).

The Warsaw cab ecology is never in equilibrium. ${ }^{8}$ It is a temporal structure that continuously recreates itself as different market participants - both individual cabdrivers and collective entities such as taxi corporations and labor unions - act and react, at various speeds, to the actions of other market participants in the context of technological innovation, drifting customs, processes of urbanization, changing market regulations, and political and economic crises.

Long (1958) theorized the city as an ecology of games: "a political game, a banking game, a contracting game, a newspaper game, a civic organization game, an ecclesiastical 
game, and many others" (p. 253). The cab ecology is one of the few games that link the participants of other games with one another. Cabdrivers link politicians with the parliamentary vote they are going to attend, journalists with a press conference, patients with their medical appointments. Cabdrivers allow individuals not only to participate in individual games but to switch between games: the politician can go to church, for example, or the banker can go home.

In other words, the Warsaw taxi market is a linking ecology. As with any other linking ecology, the cab ecology is structured by the multilayered temporal architecture of social life (Pomian 1984, 2013).

\section{THE TEMPORAL STRUCTURES OF RELIGIOUS TIME AND STATE TIME}

Underpinning Warsaw's temporal architecture is religious time and state time, extended structures that precede both the cab ecology and many of the locations of social space this ecology links.

Interactions in the Warsaw cab ecology are structured by the annual cycle of the liturgical year and the seven-day cycle that is the week (Zerubavel 1985). The religious calendar affects the rhythm of the Warsaw cab ecology not only because of Easter and Christmas but also because of the secularized tradition of celebrating name days: the feast days of the saint one is named after. During the most popular name days, such as Andrzejki (Saint Andrew's Day), the demand for taxis increases. Filip, the CEO of a midsized taxi corporation, explained, "It is as though the cabdriver is forced to work by the weather and the calendar. A popular name day — more work. The weekend — more work at night. Monday — more work during the day."

The rhythm of the cab ecology is also structured by state time. The state too is an ecology (Abbott 2016:36; see also Bourdieu 2014). One of the powers of this ecology is to shape the temporal order of social life (Bourdieu 2014:7-9, 169; Tilly 1994). In doing so, the state also shapes the temporal order of the cab ecology.

The state structures the temporal order of social life in various ways. It structures the working time of state employees: bureaucrats, police officers, teachers, and so on. ${ }^{10}$ It structures the time of other citizens by establishing temporal limits (drinking age, driving age, length of working week), schedules (public transportation, school calendar, working hours), temporal privileges (maternity leave), and temporal punishments (prison sentences). Above all, the power of the state over time relates to its control over public time and the public calendar (Bourdieu 2014:7-9). Businesspeople, lawyers, and journalists are all less likely to go to work on public holidays and thus will not take a taxi to work. ${ }^{11}$ Then, twice a year, everybody resets their clocks as the state imposes daylight saving time, thereby shifting the daily cycle of the taxi market by one hour.

The state is one of the major forces behind the emergence of universal quantitative time, and it has retained the capacity to earmark this time. ${ }^{12}$ It does this by assigning official or public meaning to certain events or periods of time: hours, days, weeks, or years. This earmarking of time is an "act of institution" (Bourdieu 1993a:119-20; see also Abbott 2001:261-79). ${ }^{13}$ The state creates a discontinuity, turning quantitative time back into qualitative time. For example, where there is a natural continuity of day becoming night, the state introduces a boundary that institutes "the day" (6 a.m. to 10 p.m.) and "the night" (10 p.m. to 6 a.m.). On a Monday at 9:59:59 p.m., a cabdriver can legally charge $x$ (where $x \leq$ $3 \mathrm{zt} / \mathrm{km}$ ) because it is "daytime," but one second later, the driver is legally allowed to charge $1.5 x$ because now it is "nighttime."

Nested within the temporal structures of the seven-day week and the public calendar are the temporal structures of other ecologies and the schedules and calendars of various 
organizations within those ecologies: enterprises, medical clinics, nightclubs, restaurants, and so on (Zerubavel 1981). When a restaurant changes its schedules, this changes the demand for taxis, as some of their employees and customers use taxis. If the seven-day week and the liturgical and public calendar are the foundations of Warsaw's temporal architecture, these temporal structures are scaffolds. Religious traditions in Poland have survived different modes of production (feudalism, capitalism, socialism, and capitalism again) and political revolutions (including the partition period during the nineteenth century, two world wars, and 40 years of secularism of the socialist regime). The public calendar has also been stable, although it was transformed by the regime changes of 1918, 1945, and 1989. These political turning points brought symbolic revolutions, which always included significant changes in public holidays. Compared with the endurance of religious time and state time, organizations usually have shorter life spans and more dynamic schedules. Put in Braudelian terms, the drifting temporal structure of religious time is part of the longue durée, state time has been restructured by the conjuncture that was the postsocialist transformation, and corporate schedules are part of histoire événementielle (Braudel 1960).

\section{THE TEMPORAL STRUCTURE OF FAMILY TIME}

Nested within the extended temporal structures of religious time and state time is family time, that is, the specific rhythms of the thousands of domestic domains of cabdrivers and their customers. The rhythms of these domains structure the rhythm of the cab ecology. And the cab ecology structures the rhythm of family life, especially cabdrivers' family life.

A home is not a hotel. One should not be a guest in one's own home. However, it is also important to be at home at the right time. Every home has a rhythm (Aubert and White 1959; Boltanski and Thévenot 2006:174; Douglas 1991:292-93; Halawa and Olcoń-Kubicka 2018). This rhythm is made out of a lineage of events that demand presence: family meals, sleeping time, celebrations. ${ }^{14}$ The rhythm of family life structures the cab ecology as cabdrivers bring businesspeople home for family dinners and allow teenagers to meet the curfew set by their parents.

Events taking place at home structure not only the demand for taxis but also the supply of taxis, which is entangled in the rhythm of cabdrivers' family lives (Occhiuto 2017:284-85). There are times when cabdrivers are unable to work because of family obligations: they have to drive children to preschool, pick up their spouses from the doctor, or get home to cook a family dinner. Because of the gendered division of housework, the influence of family time on driving time is especially clear in the rare cases of female cabdrivers, who are much more likely to have a second shift at home. But the rhythm of family life also affects some male drivers with unusual family configurations. This was the case for Jan:

I have a wife with a serious health condition, she is disabled and this means that I can only start work when I am able to, and I finish, when I have to, because she calls me and that is it. So usually in the morning there is a routine, which has to be carried out. And it cannot be predicted how this will go, because sometimes it's ok, at other times it's awful. Sometimes I start work in the morning, sometimes at 2 p.m., and some days I can't even start at all.

The rhythm of the cab ecology is coupled with the rhythms of events taking place at home. The rhythm of the cab ecology influences when cabdrivers eat, when they spend time with their family, and when they engage in leisure activities. However, the two rhythms are not always in consonance. There is often a dissonance between market rhythm and family rhythm, a dissonance that cabdrivers have to cope with. As Filip, the CEO of a midsized taxi 
corporation, repeatedly explained, "The work of a cabdriver has a flipped temporality, compared to what other people are doing." When other people are going to work, cabdrivers already have to be at work to drive them; when others are going back home, cabdrivers are in demand to drive them home. And when other people are engaged in leisure activities, cabdrivers are in demand to enable this to happen. This temporal conflict is facilitated by taxi corporations, which sometimes force drivers to work at specific times (at night, during Christmas) even though this might conflict with their family life.

Such conflicts between market time and family time occur on a daily basis. For example, there are recurring disagreements over driving at night. Family members often do not want cabdrivers to drive at night, associating nighttime with sexual activity, illegality, evil, and crime (cf. Aubert and White 1959:2). Family members and partners do not fully trust passengers using taxis at night, and they fear for the safety of their loved ones. Nor do they fully trust their loved ones, whom they fear might be using the additional advantages they associate with driving a cab at night, such as going to brothels with their male clients or hooking up with female clients.

Conflicts cumulate at specific times of the year. Probably the most significant conflict between the rhythm of the cab ecology and the rhythm of family life occurs on New Year's Eve, when there is high demand for taxis but also high demand for cabdrivers to spend time with their families. This was pointed out by Kasia, whose husband, Maciek, like the majority of cabdrivers who took my survey (64 percent), worked on New Year's Eve 2012:

My husband works every New Year's Eve. So even if we are going somewhere, I start out alone. My husband joins me around 11 p.m. He is there for midnight. An hour after midnight, 1:30 a.m., he leaves the party and goes back to work. And he works until 7 o'clock in the morning because currently this is the only day of the year where there really is a lack of taxis. ... You are not a wife and you will never be a wife so you can't understand what a woman feels if she has no company and if she is left alone. But you have to understand that this is money for the coming days - for housekeeping, for our life, or for investments.

Many cabdrivers try to cope with the demands to celebrate New Year's Eve by either staying at home or switching between driving and celebrating: leaving to work in the evening, coming home around midnight for a symbolic glass of wine, and returning to work later at night. Because many cabdrivers resort to this strategy, it becomes more difficult to hire a taxi on New Year's Eve.

To review, Davis (1959) assumed the interactions of cabdrivers and their fares to be a "random collision of particles." This prevented him from explaining the enduring structure of these interactions. Davis neglected the fact that, as Bourdieu (2005) put it, "the truth of the interaction is not to be found in the interaction itself (a two-way relation that is always in fact a three-way relation, between the two agents and the social space within which they are located)" (p. 148). I have argued that the interactions between cabdrivers and their fares have to be located in the context of a linking ecology. This ecology is entangled in the different locations of social space that it links and that are linked to it.

\section{THE TEMPORAL STRUCTURE OF WAITING TIME}

The interactions of cabdrivers and their fares are structured not only by the temporal structures of religious time, state time, and family time but also by the temporal structure of waiting time. Not only do interactions take place at a nonrandom point in time, but one side of those interactions usually has to wait for the other. 


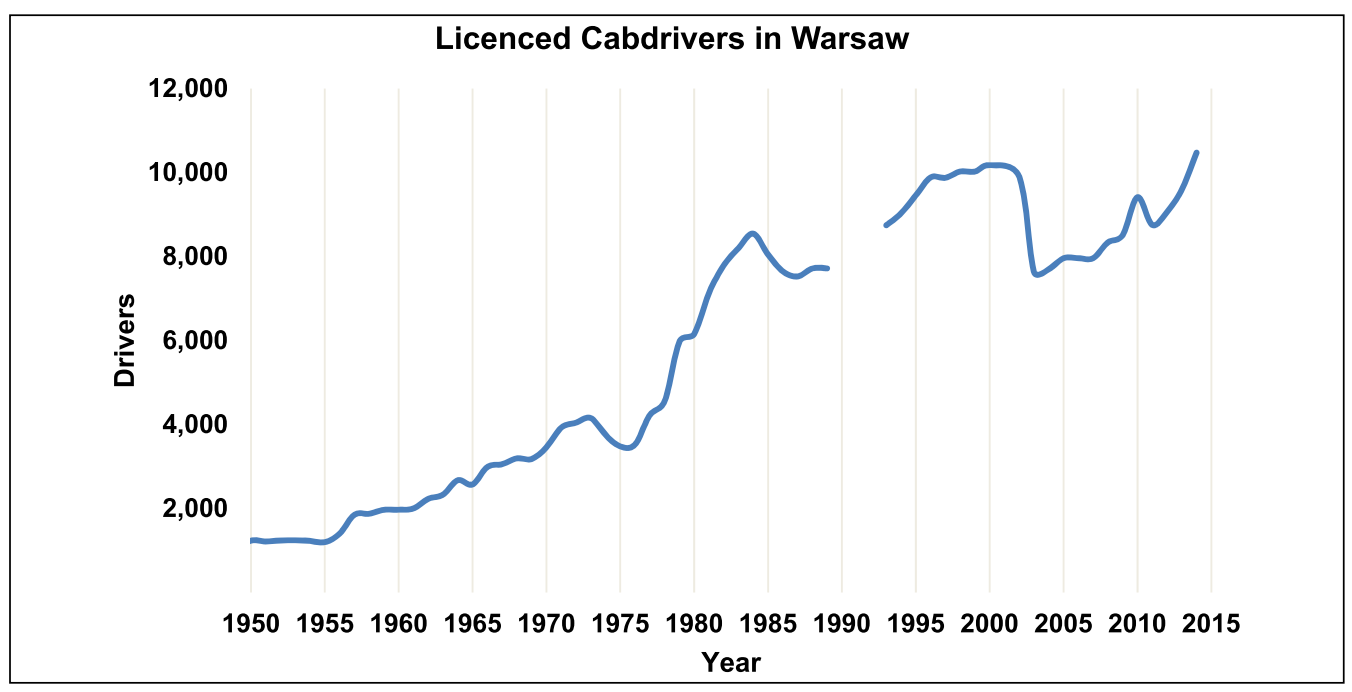

Figure I. Number of cabdrivers in Warsaw, 1950 to 2014.

Source: Data compiled from statistical yearbooks.

Note: There are no data from 1990 to 1992, when the market was completely deregulated. The data also does not include a large number of non-licenced cabdrivers who emerged after market regulation changes in $200 \mathrm{I}$ and who make up for the visible drop in the number of licenced taxi drivers.

Waiting time is ever present in the Warsaw taxi ecology. It would be extremely difficult to find a single moment when no one is waiting or, put differently, a situation of the market clearing. Waiting time does, however, constantly fluctuate, as the ecology is never in equilibrium. If we zoom in, we would see that waiting time fluctuates throughout the day, in concert with the daily flow of the city and the changing supply and demand for taxis. If we zoom out, we would see that waiting time fluctuates across days, weeks, months, and even longer periods of time. Between 1945 and 1989, it was customers who were waiting for cabdrivers; since 1989, it is mostly cabdrivers who are waiting for customers.

The history of waiting time in the Warsaw cab ecology must be located in the context of the rise and fall of the Soviet bloc and, especially, the transformation from a socialist shortage economy to a capitalist surplus economy (Kornai 2014). Between 1945 and 1989, shortages in Poland were general, frequent, intensive, and chronic: they were not limited to a certain sector of the economy; they were experienced often; they had a strong impact on the practices of individuals; and they occurred across time (Kornai 1992:233; Mazurek 2010). The persistent shortage characteristic of the socialist economy reverberated in the taxi ecology.

The shortage of taxis was largely caused by shortages of cars, spare parts, and gasoline (Brzechowska-Szawdyn 1982). The socialist economy had a persistent shortage of cars, and cars that were available were often not out on the road because of the shortage of tires, car batteries, and other car parts. In the aftermath of the 1970s oil crises, and with the number of cars in Warsaw increasing, there was a shortage of gasoline in the 1980s (Kochanowski 2010). To cope with this shortage, the state introduced a rationing policy limiting the amount of gasoline people could buy. Registered car drivers received fuel stamps for 30 to 45 liters per month, but cabdrivers received stamps for 10 liters per day. During this time, many cabdrivers would earn money not by driving but by illegally selling their petrol stamps (Kochanowski 2010:246). Although the number of cabdrivers increased in the 1980s in official statistics (see Figure 1), a shortage of taxis on the street persisted. 
Not only did shortages of cars, car parts, and gasoline limit the supply of taxis, but they also increased the demand for them. Few people owned cars, and when they did, they often could not drive them because of the lack of spare parts and gasoline. If people wanted to get somewhere, they would have to turn to taxis, which increased demand and contributed to the shortage. Shortage bred shortage.

The shortage of taxis introduced a power asymmetry in the relations of cabdrivers and their fares. Having customers wait at taxi stands put cabdrivers in a position of power. When a cabdriver arrived at a taxi stand, he could choose his next fare from a long waiting line. Breaking the basic rule of queuing (Goffman 1983:14), a cabdriver would often take not the first person in line but the one going in the direction he wanted to go. If he wanted to take a break and go home for a family dinner, as cabdrivers often did and some continue to do, he would chose a customer going in that direction, to the frustration of those standing ahead of that person in line (Brzostek 2007:300).

Warsaw's taxi shortage ended with the fall of socialism and the reintroduction of capitalism. Capitalism has a different temporal order. ${ }^{15}$ Whereas the temporal order of the socialist system was characterized by a shortage of supply and queues of people waiting for goods and services, the temporal order of capitalism is characterized by surplus supply and queues of people waiting for jobs and in unemployment offices.

The surplus supply of taxis was, to a significant extent, a product of the surplus supply of labor that emerged and persisted after 1989. After 1989, the process of privatization was restructuring the Polish economy, creating structural unemployment and forcing people to find new occupations. The surplus supply of labor began spilling over into the recently liberalized cab ecology, increasing the number of cabdrivers on the streets of Warsaw. Structural unemployment persisted as new enterprises were established, developed, and closed, forcing owners of small businesses and employees of larger companies to seek new employment. In many cases, becoming a cabdriver is not so much a career choice as a way of avoiding unemployment. Rather than join the ranks of the "reserve army of labour" that Marx spoke of, some people, particularly middle-aged men, turn to driving taxis. Asked how he became a cabdriver, Jan, a 56-year-old former carpenter who started driving in 2006, answered, not without resentment,

Completely by accident like most men and women waiting at these taxi stands. The changes that were occurring [i.e., postsocialist transformation] led to a decrease in occupational diversity. Corporations took over the market and . . . it forced me to look for something else. I never thought that I would do this [be a cabdriver] but I did. There was no alternative, no alternative, and I had a car at home.

Asked the same question, Mikołaj, a 57-year-old driver who started a few months earlier, answered,

I once had a plan to become a cabdriver, but I thought that I could do more with my life then to drive a taxi. This idea returned when my other plans were thwarted. I had to close down my business.

With the number of cabdrivers increasing, the temporal structure of the cab ecology changed. Cabdrivers begin to wait, and time spent waiting is unpaid. As independent contractors, nearly all cabdrivers only earn money when they are driving with a client. ${ }^{16}$ In other words, if we define "work" as an activity done in exchange for money, as most economic models do, then cabdrivers are currently not "working" for much of the time spent "at work". 
With the change in the temporal structure of waiting time came a change in the power relation between cabdrivers and their fares. After 1989, cabdrivers lost much of the power they wielded over their fares. They were no longer able to pick and choose their fares at taxi stands. It was now their turn to wait. ${ }^{17}$

\section{FISHING FOR CUSTOMERS: UNCERTAINTY AND WAITING TIME}

Waiting time is a temporal structure because it shapes who interacts with whom, when, where, and for how long and also because it reflects and reproduces the power relation between cabdrivers and their fares (Bourdieu 2000:228-29; Schwartz 1974). And waiting time is a temporal structure because, as I will argue, it is continually remade out of cabdrivers' defensive and adaptive strategies and the repetitive and unique events taking place across the social space.

The temporal structure of waiting time must be located in the context of the transformation from socialism to capitalism. However, cabdrivers wait for customers not because of hidden overarching historical forces but because these forces are continuously encoded in the flow of the social process that is the cab ecology. Capturing this process of encoding requires a switch from a structural mode of analysis to a lyrical mode: investigate temporality not as a sequence of events but rather as the experience of passage from one event to the next (Abbott 2016:7778 , cf. Tavory 2018). A phenomenological account that looks at the experience of passage is required because, contrary to Davis's metaphor of the taxi market as an atomic field, cabdrivers cannot be reduced to mere physical particles bumping into their fares at random. Unlike particles, cabdrivers have anticipations and strategies, and it is through their anticipations and strategies that waiting time is encoded from moment to moment. ${ }^{18}$

Demand for cabs is shaped by the rhythms of the different locations of social space that cab ecologies link. But demand is also experienced (first anticipated and then remembered) by cabdrivers. This experience is perhaps best captured by the metaphor of cabdriving as fishing, which cabdrivers in Warsaw, and elsewhere (Sharma 2014:65), often use to describe their work. Artur, a 31-year-old husband and father who was the sole income producer in his family, explained,

Artur: [I tell my wife] "Listen darling, I am going to work-maybe I will earn something." But then you go to work and you don't earn anything. You are angry that you should have stayed at home. But on the other hand, if you had not gone to work, you would not have known whether it made sense or not. It is like [pause] . . like fishing! You go and you do not know what you will catch.

Me: I have noticed that many cabdrivers use this metaphor.

Artur: Because it is true! It is true! You go fishing. You sit on the dock. You do not know what you will catch. Within an hour you might have a whole bucket of fish and you might go home or you could sit for two days and not catch anything.

The fishing metaphor captures how cabdrivers experience passage from one fare to the next. It shows this to be a moment of uncertainty (Beckert 1996). This uncertainty is at the root of many of their emotions: hope (related to future earnings), disappointment and regret (related to past choices), and frustration and anger (related to their present situation). The fishing metaphor also illuminates the relationship between uncertainty and waiting time. Often, cabdrivers do not know what types of customers they will get (Davis 1959; Gambetta and Hamill 2005), nor when this customer will come. Will they wait five minutes and catch a long fare, or wait an hour and catch a short one and wait again? In this situation of uncertainty, the element of time becomes central (Menger 2014:45-47). 


\section{THE MARKET PROCESS AND THE EVENTFULNESS OF DEMAND}

Uncertainty in the cab ecology comes from both supply and demand. On the supply side, uncertainty is related to the welter of actors competing for fares. A cabdriver is simply unable to perfectly anticipate the strategies of all the other cabdrivers, especially because, as I will argue, each driver has a surfeit of strategies to choose from. On the demand side, with thousands of fares every day, uncertainty comes from the excess of clients and the lack of knowledge about them. But it also comes from the eventfulness of demand.

Any market is a social process. What we refer to as "the Warsaw taxi market" is a lineage of events overlapping in time (Kornai 1971:226, 2014:60-61). In the taxi market, each fare is an event: a local consummation of actions and interactions that sends out constraints and potentialities into the future.

Fares can be divided into repetitive and unique. ${ }^{19}$ At least in theory, an experienced cabdriver should be able to anticipate repetitive fares, precisely because they happen regularly. And, contrary to what Davis (1959:159) wrote about Chicago (cf. Anderson 2004:169-72), in Warsaw there are many such predictable fares. Repetitive fares are the result of the millions of schedules and routines that make up any city. The repetitiveness of fares in Warsaw is increased by the fact that customers, either out of routine or because of a contract, call the same taxi corporation to order a taxi. Artur told me,

You know more or less what time more trains are due to arrive or planes due to land and when there is more movement. ... If you work for a larger [taxi] corporation, you more or less know what time employees are going out en masse and taking taxis.

By participating in the cab ecology and interacting with others, cabdrivers acquire "rhythm expertise" (Snyder 2016:102-107). They get to know the schedules of different organizations and the routines of individual clients. They acquire a "stock of knowledge" (Daipha 2015:9; Schutz 1959), which helps them synchronize with the rhythm of the city and anticipate the demand for their service.

But there are also unique fares. ${ }^{20}$ Because the taxi market is a linking ecology, both repetitive and unique events that take place across the broader social space reverberate in it. A small unique event reverberating in the cab ecology is a woman waking up late and taking a taxi to work, rather than her usual bus. A larger unique event is a disruption to the subway system that forces many commuters to look for alternative forms of transportation at the same time. As Hughes (1951:320) would have put it, cabdrivers' work routines are made up, in part, of the emergencies of other people. These emergencies often cannot be ancitipted.

Fares overlap. Like any other event, they have duration. It takes time to travel across the city to get to a customer and also to travel with customers to their destination. This can lead to conflict over speed, as customers may be running out of time or are already late and want to get to their destination as fast as possible, whereas cabdrivers want to avoid getting a ticket or crashing their cars. The duration of a fare is thus not a direct function of physical distance, traffic, and driving laws but is influenced by cabdrivers and their fares negotiating the speed of the cab during their fleeting interaction. ${ }^{21}$ The outcomes of these negotiations affect the structure of the cab ecology: which cabdriver will end up picking up which customer, when and where, how long everyone will wait, and how much cabdrivers will earn.

Because fares overlap, despite what cabdrivers say during interviews, finding customers is not like a game of roulette: it is not a series of perfectly independent occurrences. Finding customers is a game in which each fare is structured by the immediate past, that is, by the last position-takings of other players (taxi corporations and cabdrivers), which in turn structure the next positions of those players and thereby the next iteration of the ecology. For 
cabdrivers, each fare provides a gateway to subsequent fares but also "restricts the space of possibles open to them" (Bourdieu 2005:195). Picking up client X will enable a taxi driver to pick up next client $\mathrm{Y}$ or $\mathrm{Z}$ but not $\mathrm{Q}, \mathrm{R}$, and $\mathrm{W}$. In other words, the social structure that anchors the interactions of cabdrivers and their fares is reproduced from moment to moment. It is a temporal structure.

The market process is not a succession of independent occurrences but a lineage of overlapping events. For a cabdriver to rationally plan the day ahead and maximize daily income would therefore require knowledge of the space-time position of each potential customer throughout the day, their destinations, the traffic situation at that time and thus the duration of each potential journey, and the exact plans of all the other cabdrivers with whom the cabdriver is competing for fares. Such perfect knowledge would then allow the cabdriver to choose the optimal combination of clients. With such a portfolio of clients, a driver would be able to maximize income while limiting waiting time. However, this model of action has very little to do with what cabdrivers actually do when they go to work. For a cabdriver, planning a whole day of work ahead of time would be like trying to predict the unfolding of a whole game of chess in advance (Leifer 1991).

\section{DEFENSIVE STRATEGIES: COPING WITH UNCERTAINTY THROUGH ROUTINES}

If the temporal structure of the Warsaw taxi ecology is shaped by the state, capitalism, and religious traditions, this is because these extended social forces are continually encoded by cabdrivers coping with uncertainty. Thus, having investigated one blade of Herbert Simon's scissors, the task environment that I theorized as a linking ecology, it is now time to take a closer look at the other blade: the actors populating this ecology and coping with this task.

One way cabdrivers can deal with uncertainty is through routines. For cabdrivers, routines tame excess and establish a sense of control (Santee 1989:135). Warsaw cabdrivers use routines related to space, time, movement, customers, and income. First, spatial routines relate to coming back to the same location. There are drivers who always return to the same taxi stand. These drivers are known as gumiarze: people who act as if they were held by an elastic band (guma). After dropping off a fare, gumiarze return to the same taxi stand to wait for the next one. Second, cabdrivers use a temporal routine, or a working schedule. Unlike the majority of drivers in New York (Occhiuto 2017), cabdrivers in Warsaw do not work shifts but are able to choose when they work. Nevertheless, many drivers end up working a schedule. Adam, for example, often started his day at 7:30 to 7:40 a.m. by driving his child to school and then his wife to work. Third, cabdrivers use a routine of movement. A cabdriver tries to move as little as possible between customers; drivers do not drive looking for fares but wait in one place. This strategy is facilitated by dispatch systems that allow drivers to wait in one location but receive a fare from another location. Fourth, cabdrivers have routines related to regular clients. Although cabdrivers usually avoid making commitments to individual clients, unless they are family or friends, they become attached to corporate clients through their taxi corporations, which sign contracts with various companies to drive their employees. Finally, cabdrivers rely on income routines. Many cabdrivers try to earn a certain revenue each day; depending on the taxi corporation, this is usually around 200 to 300 PLN (\$60-\$90). The income routine is what behavioral economists call an income target (Camerer et al. 1997). Some drivers in Warsaw use an income target consciously, and some use it without necessarily being aware of this.

The temporal architecture of urban life is highly complex. Taxi ecologies link the components of this architecture. Taxi corporations and cabdrivers cope with this task, as well as 
with competition, by using defensive strategies that focus on a certain segment of this architecture (temporal or spatial). Although I described the five routines separately, few cabdrivers rely on just one routine. Contrary to the various models of neoclassical and behavioral economists (e.g. Camerer et al. 1997, Crawford and Meng 2011, Farber 2005), there is no "representative agent" (Kirman 1992) in the taxi market. Each cabdriver develops a more or less unique style of driving that is made up of different routines.

\section{ADAPTIVE STRATEGIES: COPING WITH UNCERTAINTY THROUGH OBSERVATION}

The adoption of routines is one strategy for dealing with uncertainty, the other strategy is observation. Whereas relying on routines is a "defensive strategy," observation is an "adaptive strategy" (Abbott 2016:153-56).

Adapting to the market process requires observing this process (Geertz 1978:30; White 1981:518). And cabdrivers do observe the taxi ecology. They observe taxi stands to see the current supply of taxis, and they observe the weather, especially looking for any signs of rain, to anticipate the demand for their service.

Cabdrivers observe the market process not only by looking out their car windows but also by using different "instruments of observation" (Pomian 1998:226). The main instruments of observation that help them synchronize with demand for their service are the clock and the taxi terminal.

In Warsaw, most fares are not hailed on the street or taken from taxi stands but ordered by phone. A passenger orders a taxi by calling a corporation and talking to a dispatcher. Passengers are then distributed in a "cognitive ecology" (Hutchins 2010) comprising taxi dispatchers, cabdrivers, and taxi terminals.

The distribution of fares within a taxi corporation is done through a zone system. Each taxi corporation divides the city into zones (see Figure 2). To receive the fare, a driver must be first in line in the appropriate zone. If there is no driver in that particular zone, the fare becomes "free" and is taken by the first driver to press the appropriate button on the terminal located in his or her car.

The terminal not only allows drivers to sign up in a zone and receive fares, but it also allows them to see how many taxis are signed up in each zone and the number of prebooked fares in each zone. The terminal thus extends cabdrivers' "response presence" (Goffman 1983:2). It allows them to observe and react to the actions of other actors even though they are physically far away, thereby transforming both the interaction order and the structure of the cab ecology.

Because customers, either out of routine or because of a contract, often use one taxi corporation, most of the day-to-day competition in the Warsaw cab ecology is not among taxi corporations but between drivers from the same corporation. Most competition takes the form of local competition (cf. Levin 2009:49). Cabdrivers deal with local competition by looking for locational niches. The niches constructed by taxi corporations are institutionalized through contracts and customs. The niches cabdrivers occupy are not institutionalized; rather, they constantly appear and disappear as drivers act and react to the behavior of other drivers from their corporation. Put differently, the speed of the game played by cabdrivers is much faster than the speed of the game played by taxi corporations. Taxi corporations move - for example, by acquiring a new taxi stand or a new corporate customer - on a weekly or monthly basis, whereas cabdrivers move several times each day.

Cabdrivers use the taxi terminal to adapt their next move. They use the terminal to position themselves in relation to other cabdrivers from their corporation and the anticipated 


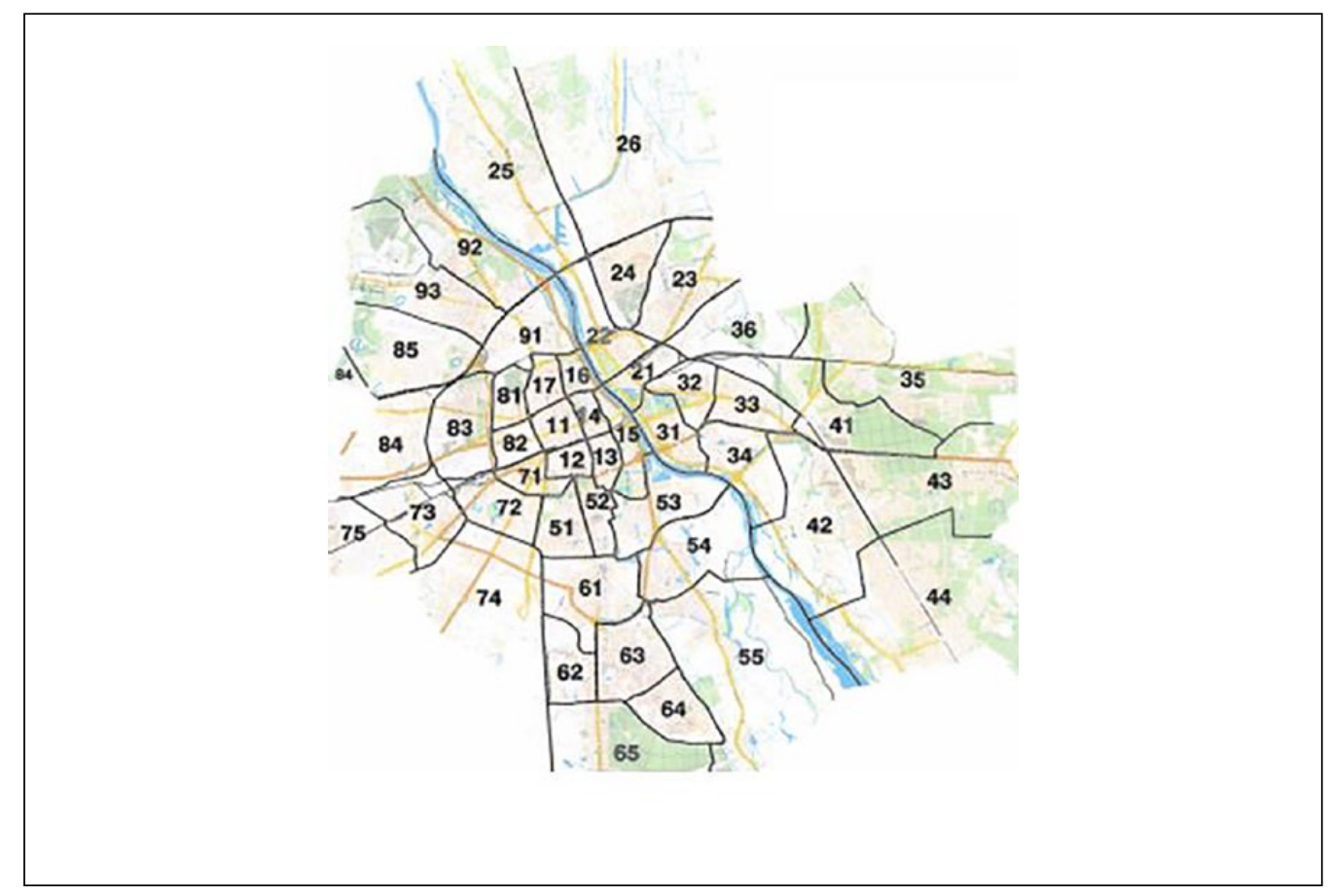

Figure 2. The division of Warsaw into zones by one of the taxi corporations.

demand in different zones of the city. Although cabdrivers cannot predict how the taxi game will unfold many moves in advance, they can adapt their next move. They adapt by looking for locational niches. However, with a surplus supply of taxis, finding such a locational niche is like finding a fast lane while stuck in a traffic jam.

Cabdrivers' decisions regarding where to go next are not carefully planned but are made in the heat of the moment. Bartek, a 42-year-old who used to be an ambulance driver before becoming a cabdriver in the late 1990s, explained his decision-making process:

It's just like deciding, when approaching a crossroad, whether you will make it before the other car or not. This is the amount of time that you have. . . I look [at the taxi terminal]. At the central station there are so many [taxis]. In this area there are so many. In that area there are so many. But wait, what time is it? Oh, maybe a train will come soon. So even though there are 30 cabdrivers at the central station, I will sign in there and soon leave [with a fare]. There is a split-second to make a decision. A then it's just about the skill of your fingers to hit the right buttons [on the terminal].

Because of temporal urgency, cabdrivers' decisions are not guided by rational expectations (cf. Crawford and Meng 2011; Farber 2005, 2015). There is simply too little time, too little knowledge, and too many possible strategies to calculate. Nor are their adaptive strategies guided by a single rule of thumb in the form of an income target (cf. Camerer et al. 1997). An income target sometimes guides a cabdriver's decision of whether to continue working or go home, but it cannot guide where to go next. Rather, cabdrivers' adaptive strategies are guided by "practical anticipations" (Bourdieu 2005:196) or "protentions" (Tavory and Eliasoph 2013:912-13). Cabdrivers' protentions - which have been undertheorized as "gut feelings" (Gambetta and Hamil 2005:216-19) — are developed in a process 
of cultural learning: by interacting with other drivers, customers, dispatchers, and owners of taxi corporations.

With experience, cabdrivers develop an ecological rationality (Todd and Gigerenzer 2012) or a practical sense (Bourdieu 2000). This practical sense allows them to synchronize with the rhythm of the city. ${ }^{22}$ However, contrary to what Bourdieu $(2000: 147,208)$ emphasized, we should not speak about a "perfect coincidence of practical schemes and objective structures" or a "quasi-perfect coincidence between habitus and habitat, illusio and lusiones, expectations and the world." If there were "perfect coincidence" between demand and cabdrivers' anticipations of demand, then surplus supply and waiting time would be an exception rather than, as it is, the norm. Even with a "feel for the game" (Bourdieu 2000:151), the game is simply too complex and too unpredictable to be played perfectly.

Put simply, cabdrivers make mistakes. ${ }^{23}$ A consequential mistake is an overinvestment of time spent driving. The time Warsaw cabdrivers can spend in their cabs is not constrained by state regulation, as in Paris, or by the need to return their cars, as in New York. It is also not constrained by the lack of gasoline, as in Poland during the gasoline shortage of the 1980s. Put differently, there are rarely "hard" constraints on working time. Instead, drivers experience "soft" constraints: a family member calling them to come home for dinner or a feeling of fatigue or boredom. But such soft constraints can easily lead to overinvestment of time spent at work. ${ }^{24}$ Individual cabdrivers pay for overinvesting time by waiting, but their mistakes also reverberate throughout the cab ecology, as waiting time gets redistributed among drivers whose actions are interlocked by competition. ${ }^{25}$

To summarize, waiting time in the Warsaw cab ecology is a product of the postsocialist transformation and capitalist dynamics, but only because these forces are continually encoded through cabdrivers' defensive and adaptive strategies. Following Abbott (2016), we can say that Warsaw cabdrivers "make their own histories, but . . . in that making they produce extended structures that in turn render them unable to make those histories under conditions of their own choosing" (pp. 34-35). What emerges and is reproduced through cabdrivers' defensive and adaptive strategies is surplus supply and a temporal structure of waiting time. ${ }^{26}$

\section{CONCLUSIONS}

In the epigraph of this article, Fred Davis (1959) theorized interactions of cabdrivers and their fares as random collision of particles in an atomic field. In this article I have explained why, to paraphrase Geertz (1978:30), this apparent Brownian motion of randomly colliding particles conceals resilient patterns of social life. The couplings of cabdrivers and their fares are far from random events. I developed an ecological and processual explanation as to why this is the case. This explanation was ecological because it looked both at the location of the cab ecology in the temporal architecture of urban life as well as the way cabdrivers respond to the uncertainties and apparent random connections of this architecture (Bateson 1967:29). ${ }^{27}$ The explanation was processual because it focused on how this architecture is continually remade (Abbott 2016:73).

Like many other members of the second Chicago School, Davis (1959, 1982) was interested in the symbolic dimension of interaction (Fine 1995:115-118). I argued that interactions are located in a temporal structure. This temporal structure anchors who is interacting with whom, when, where, and for how long. It both reflects and reproduces the power relation in the interaction. The temporal structure is a product of the social process: it emerges out of historical legacies (in the studied case, Catholic traditions and the postsocialist transformation), institutional rhythms (liturgical year, state calendar, organizational schedules, and family rhythms), event durations (durations of contracts 
and fares), and the defensive and adaptive strategies of cabdrivers and their fares (their routines and observations).

The interactions of cabdrivers and their fares are not the outcome of a random collision of particles, as Davis argued. Nor are they the outcome of some mysterious invisible hand coordinating market activities, as believed by neoclassical economics. They are also not the outcome of actors only following simple heuristics, as in behavioral economics. To help us understand how cabdrivers and their fares end up meeting, we could draw on Bourdieu's (2005:73) musical metaphor of a "spontaneous orchestration of practices," but only if we remember that because there is no grand conductor, this orchestration is far from perfect. Not only do we find a cacophony of political contestation (Serafin 2016), but the synchronization of supply and demand is also not harmonious. Since 1989, a temporal structure of cabdrivers waiting for customers endures, even though both cabdrivers and their fares are constantly moving in geographic space (across the city) and in social space (starting families, taking on new occupations, moving within those occupations, retiring).

To capture the temporal structures of the Warsaw taxi ecology, I have developed the notion of a linking ecology. The theoretical section provided a few other examples of linking ecologies and discussed their properties. In conclusion, I would like to provide one final example to show how the notion applies beyond the case analyzed here.

In the media ecology, various organizations and individuals compete to link the public with events taking place in different ecologies: political events, sporting events, religious events, gossip about celebrities, and so on. ${ }^{28}$ The rhythm of the media ecology comprises the rhythms of the various locations linked by the media: the routine press conferences and presidential addresses (repetitive and unique events in the political ecology), transmissions of masses and elections of the pope (repetitive and unique events in the religious ecology), and press conferences after games and doping scandals (repetitive and unique events in the sport ecology). News organizations and journalists compete to link faster than others: to provide breaking news and get a scoop. ${ }^{29}$ They deal with competition by constructing and occupying niches: focusing on particular events or a particular interpretation of those events. ${ }^{30}$ They rely on routines and observation. As the media ecology has grown and become powerful, a strong feedback has developed from this ecology to the locations it links. Like the development of the maritime ecology and globalization, and the development of the financial ecology and financialization, the development of the media ecology has formed the backbone of mediatization, a process that is transforming politics, sports, war, science and other human endeavors (Couldry and Hepp 2013).

To conclude, the notion of a linking ecology draws attention to the fact that what Chicago sociologists liked to call "the web of life" is woven together not only by avatars and hinges but also by more complex structures that are themselves semiautonomous arenas of competition. A natural history of linking ecologies - a theory that would explain why linking ecologies emerge and how they coevolve with their environment, as well as capture in more detail their specific properties - would surely deepen our understanding of the social process.

\section{ACKNOWLEDGMENTS}

I would like to thank Thomas Angeletti, Jens Beckert, Zofia Boni, Felipe Gonzalez, Markus Lang, and Mateusz Halawa, as well as the various anonymous reviewers of this article, whose comments on previous versions greatly improved it. A very early version of this article was presented at SASE 2015 in London. Finally, I would also like to thank my research assistants Maja Durlik, Paweł Głapiński, Tomasz Głapiński, and Alicja Murawska for assisting with distribution of the survey for this study. 


\section{NOTES}

1. I would like to thank a reviewer for pointing out to me what is temporal about temporal structures.

2. In this general sense, Bourdieu can be treated as an ecological theorist. Bourdieu (2000:150) theorized the social process as "the encounter of two histories": "objectified history" and "embodied history" or, put differently, field and habitus. In this article I draw from ecological theory and field theory. For a comparison of the two approaches, see Liu and Emirbayer (2016).

3. Taxi stands used to be one of the most important "uncertainty reducing institutions" (Bourdieu 2005:196). With the invention of dispatch systems and mobile phones, stands have lost much of their power. Nevertheless, they continue to play an important role as taxi corporations and groups of drivers compete over access to valuable taxi stands near airports, train stations, and clubs.

4. Studies using ecological theory and field theory usually provide a synchronic analysis that maps out positions in space or provides snapshots showing change of positions over time, but they neglect the "temporality of the moment" (Abbott 2016:77).

5. For the history of taxis in Paris see Papayanis (1996), for London see Georgano (1972), and for New York see Hodges (2007) and Mathew (2008).

6. There were Jewish cabdrivers in Warsaw before World War II.

7. For the work of dispatchers, see Anderson (2004).

8. Processual sociology is incompatible with the notion of equilibrium (Abbott 2016:204). "A state of equilibrium, by definition, is a state in which something relevant is not changing: therefore, the use of an equilibrium concept is itself a signal that the role of time is, at least to some extent, neglected" (Zamagni and Agliardi 2004:xv; see also Arthur 2014:1-29; Kornai 1971).

9. All interviews were conducted in Polish; translations are mine.

10. In 2014 in Warsaw, this was almost 300,000 people out of about 1.7 million inhabitants.

11. Among the 13 public holidays, 8 have origins in the religious calendar. Seven of those are guaranteed not only by national law but also by the concordat the Polish state signed with the Vatican in 1993.

12. For the history of universal time and the role of the state in this process, see Dohrn-Van Rossum (1996) and Galison (2004).

13. "The act of institution is the act of social magic that can create difference ex nihilo, or else (as is more often the case) by exploring as it were pre-existing differences ... [this] social magic always manages to produce discontinuity of the continuity" (Bourdieu 1993:119-20).

14. Family events are nested in family trajectories of people establishing families and their children growing up and more extended processes such as women's increasing participation in the labor market.

15. On the temporal order of capitalism, see Beckert (2016), Halawa (2015), Sewell (2008), and Snyder (2016).

16. In 2013, there was one taxi corporation in Warsaw that paid by the hour.

17. When I refer to the shift from a shortage of taxis before 1989 to a surplus after 1989, I am describing a general pattern, to which many exceptions can be found, New Year's Eve being the prime example.

18. A phenomenological account helps avoid not only the mechanistic view but also "the scholastic point of view" (Bourdieu 2000:146-47), which characterizes the neoclassical models of cabdrivers' behavior that bear little resemblance to the actual experience of driving a taxi (cf. Crawford and Meng 2011, Farber 2005, 2015).

19. The economist Gordon C. Winston (1988:39-44) pointed out the theoretical significance of the distinction between unique and repetitive events. He argued that one of the main tools of neoclassical economics, rational choice theory, is ill equipped to study unique events.

20. Of course, all fares are in some way unique. A ride from $\mathrm{A}$ to $\mathrm{B}$ at $t_{1}$ is different from $\mathrm{B}$ to $\mathrm{A}$ or $\mathrm{A}$ to $\mathrm{C}$ or A to B at $t_{2}$. Nevertheless, we can speak about fares as repetitive when they happen regularly and can, at least in theory, be predicted (cf. Winston 1988:43).

21. Taxi dispatchers are often involved, pushing drivers to arrive faster at pickup locations.

22. Economists have shown how experienced cabdrivers are better at anticipating demand (Haggag, McManus, and Paci 2017), and neurologists have shown how their brains are differently structured (Maguire et al. 2000).

23. Bourdieu (2000:160) theorized actors' maladjustments in the context of large-scale transformation, crises, and social mobility. He neglected, however, the small maladjustments of everyday life (Lahire 2011:45-48). It was Hughes (1951) who emphasized the importance of mundane mistakes for social life. 
24. The distinction between soft and hard constraints was made by Kornai (1992:140-43). Kornai was speaking about the effects of soft constraints on the overinvestment of capital, but his argument can be extended to working time.

25. Although cabdrivers complain about waiting, waiting is not always irksome. This is especially the case when cabdrivers use work to avoid household chores and family conflicts.

26. This article focused on how encoding of waiting time involves action, but it also suggested a more complete analysis of encoding that includes meaning and emotion, which are the other two "zones of human experience" (Abbott 2016:21). In relation to meaning, waiting is reproduced, in part, with the fishing analogy (mentioned earlier) that taxi drivers use to symbolize their work. The fishing analogy legitimizes waiting as a natural phenomenon, even though it is a social outcome, thereby routinizing it and preventing it from becoming a political issue. Regarding emotions, taxi drivers' wait for customers is, in part, a reproduction of hope. Much like gamblers, taxi drivers are extending their working time "living in the hope of making up in one final sweep of winnings an amount sufficient to compensate for ... previous losses" (Bloch 1951:219).

27. I am grateful to a reviewer whose remarks led to the formulation of this sentence.

28. I would like to thank Mateusz Halawa for this example.

29. Park (1940:676) pointed out the temporal structure of the media ecology; he argued that news is a "perishable commodity" that exists only in a "specious present" and "[once] published and its significance recognized, what was news becomes history." The notion of linking ecology allows us to rethink Park's $(1923,1940,1941)$ classical writings on news.

30. For example, Aday, Livingston, and Hebert (2005:13) showed how the war in Iraq was differently covered by different TV networks. Fox News and CNN focused more than the other networks on battles, whereas $\mathrm{ABC}, \mathrm{NBC}$, and $\mathrm{CBS}$ focused more on casualties.

\section{REFERENCES}

Abbott, Andrew. 2001. Time Matters. Chicago: University of Chicago Press.

Abbott, Andrew. 2002. "Los Angeles and the Chicago School: A Comment on Michael Dear." City \& Community 1(1):33-38.

Abbott, Andrew. 2016. Processual Sociology. Chicago: Chicago University Press.

Aday, Sean, Steven Livingston, and Maeve Hebert. 2005. "Embedding the Truth: A Cross-Cultural Analysis of Objectivity and Television Coverage of the Iraq War." Harvard International Journal of Press 10(1):3-21.

Anderson, Donald N. 2004. "Playing for Hire: Discourse, Knowledge, and Strategies of Cabdriving in San Francisco." Master's thesis, California State University.

Arthur, Brian. 2014. Complexity Economics. Oxford, UK: Oxford University Press.

Aubert, Vilhelm, and Harrison White. 1959. "Sleep: A Sociological Interpretation II." Acta Sociologica 4(3):1-16.

Bateson, Gregory 1967. “Cybernetic Explanation.” American Behavioral Scientist 10(8):29-32.

Beckert, Jens. 1996. "What Is Sociological about Economic Sociology? Uncertainty and the Embeddedness of Economic Action." Theory and Society 25(6):803-40.

Beckert, Jens. 2016. Imagined Futures. Cambridge, MA: Harvard University Press.

Bloch, Herbert. 1951. "The Sociology of Gambling." American Journal of Sociology 57(3):215-21.

Boltanski, Luc, and Laurent Thévenot. 2006. On Justification. Princeton, NJ: Princeton University Press.

Bourdieu, Pierre. 1993a. "Rites of Institution." Pp. 117-27 in Language and Symbolic Power, edited by P. Bourdieu and J. Thompson. Cambridge, MA: Harvard University Press.

Bourdieu, Pierre. 1993b. "Some Properties of Fields." Pp 72-77 in Sociology in Question. London, UK: Sage Ltd.

Bourdieu, Pierre. 2000. Pascalian Meditations. Stanford, CA: Stanford University Press.

Bourdieu, Pierre. 2005. The Social Structures of the Economy. Cambridge, UK: Polity Press.

Bourdieu, Pierre. 2014. On the State. Cambridge, UK: Polity Press.

Bourdieu, Pierre. 2015. Sociologie Générale. Vol. 1. Paris: Le Seuil.

Braudel, Fernand. 1960. "History and the Social Sciences: The Long Duration." American Behavioral Scientist 3(6):3-13. 
Braudel, Fernand. 1995. The Mediterranean and the Mediterranean World in the Age of Philip II. Vol. 2. Berkeley: University of California Press.

Bretagnolle, Anne. 2015. "City-Systems and Maritime Transport in the Long Term." Pp. 27-36 in Maritime Networks, edited by C. Ducruet. London: Routledge.

Brzechowska-Szawdyn, Magdalena. 1982. "Taksówki Osobowe w Warszawie—Podstawy Organizacyjne i Ekonomiczne Działalności Usługowej.” Master's thesis, Warsaw School of Economics.

Brzostek, Błażej. 2007. Za Progiem. Warsaw, Poland: Wydawnictwo Trio.

Camerer, Colin, Linda Babcock, George Loewenstein, and Richard Thaler. 1997. "Labor Supply of New York City Cabdrivers: One Day at a Time.” Quarterly Journal of Economics 112(2):407-41.

Carnegy, Hugh. 2014. "Court Victory for French Online Taxi Operators." Financial Times, February 5. Retrieved May 11, 2019. https://www.ft.com/content/260d22b0-8e68-11e3-98c6-00144feab7de.

Cicourel, Aaron. 2006. "Cognitive/Affective Processes, Social Interaction, and Social Structure as Representational Re-descriptions: Their Contrastive Bandwidths and Spatio-temporal Foci." Mind \& Society 5(1):39-70.

Couldry, Nick, and Andreas Hepp. 2013. "Conceptualizing Mediatization: Contexts, Traditions, Arguments." Communication Theory 23(3):191-202.

Crawford, Vincent P., and Juanjuan Meng. 2011. "New York City Cab Drivers' Labor Supply Revisited: Reference-dependent Preferences with Rational-expectations Targets for Hours and Income." American Economic Review 101(5): 1912-32.

Daipha, Phaedra. 2015. Masters of Uncertainty. Chicago: Chicago University Press.

Darbéra, Richard. 2010a. "Taxicab Regulation and Urban Residents' Use and Perception of Taxi Services: A Survey in Eight Cities." Paper presented at the 12th World Conference on Transport Research, Lisbon, Portugal.

Darbéra, Richard. 2010b. "Where Are the Taxis Going? A History of Regulatory Disruption." Paper presented at the 12th World Conference on Transport Research, Lisbon, Portugal.

Davis, Fred. 1959. "The Cabdriver and His Fare: Facets of a Fleeting Relationship." American Journal of Sociology 65(2):158-65.

Davis, Fred. 1982. "On the 'Symbolic' in Symbolic Interaction.” Symbolic Interaction 5(1):111-26.

Davis, Gerald, and Suntae Kim. 2015. "Financialization of the Economy." Annual Review of Sociology 41:203-21.

Dohrn-van Rossum, Gerhard. 1996. History of the Hour. Chicago: University of Chicago Press.

Douglas, Mary. 1991. "The Idea of a Home: A Kind of Space." Social Research: An International Quarterly 58(1):287-307.

Erikson, Emily, and Peter Bearman. 2006. "Malfeasance and the Foundations for Global Trade: The Structure of English Trade in the East Indies, 1601-1833. American Journal of Sociology 112(1):195230 .

Evans, Rhonda, and Tamara Kay. 2008. "How Environmentalists 'Greened' Trade Policy: Strategic Action and the Architecture of Field Overlap." American Sociological Review 73(6):970-91.

Eyal, Gil. 2013. "Spaces between Fields." Pp. 158-82 in Bourdieu and Historical Analysis, edited by P. S. Gorski. Durham, NC: Duke University Press.

Farber, Henry S. 2005. "Is Tomorrow Another Day? The Labor Supply of New York City Cabdrivers." Journal of Political Economy 113(1):46-82.

Farber, Henry S. 2015. "Why You Can't Find a Taxi in the Rain and Other Labor Supply Lessons from Cab Drivers." Quarterly Journal of Economics 130(4):1975-2026.

Fine, Gary A., ed. 1995. A Second Chicago School? Chicago: University of Chicago Press.

French, Shaun, Andrew Leyshon, and Thomas Wainwright. 2011. "Financializing Space, Spacing Financialization." Progress in Human Geography 35(6):798-819.

Galison, Peter. 2004. Einstein's Clocks and Poincaré's Maps. New York: W.W. Norton.

Gambetta, Diego, and Heather Hamill. 2005. Streetwise. New York: Russell Sage.

Geertz, Clifford. 1978. "The Bazaar Economy: Information and Search in Peasant Marketing." American Economic Review 68(2):28-32.

Georgano, G. N. 1972. A History of the London Taxicab. Newton Abbot, UK: David \& Charles.

Goffman, Erving. 1983. "The Interaction Order: American Sociological Association, 1982 Presidential Address." American Sociological Review 48(1):1-17. 
Haggag, Kareem, Brian McManus, and Giovanni Paci. 2017. "Learning by Driving: Productivity Improvements by New York City Taxi Drivers." American Economic Journal: Applied Economics 9(1):70-95.

Halawa, Mateusz. 2015. "In New Warsaw: Mortgage Credit and the Unfolding of Space and Time." Cultural Studies 29(5-6):707-32.

Halawa, Mateusz, and Marta Olcoń-Kubicka. 2018. "Digital Householding: Calculating and Moralizing Domestic Life through Homemade Spreadsheets." Journal of Cultural Economy 11(6):514-34.

Hodges, Graham Russell. 2007. Taxi! Baltimore, MD: Johns Hopkins University Press.

Hollingshead, A. B. 1939. "Human Ecology." Pp. 65-168 in An Outline of the Principles of Sociology, edited by R. Park. New York: Barnes \& Noble.

Hutchins, Edwin. 2010. “Cognitive Ecology.” Topics in Cognitive Science 2(4):705-15.

Hughes, Everett. 1951. "Mistakes at Work." Canadian Journal of Economics and Political Science 17(3):320-27.

Kirman, Alan. 1992. "Whom or What Does the Representative Individual Represent?" Journal of Economic Perspectives 6(2):117-36.

Kochanowski, Jerzy. 2010. Tylnymi Drzwiami. Warsaw, Poland: Wydawnictwo Neriton.

Kornai, János. 1971. Anti-equilibrium. Amsterdam, the Netherlands: North-Holland.

Kornai, János. 1992. The Socialist System. New York: Oxford University Press.

Kornai, János. 2014. "Shortage Economy_Surplus Economy." Pp. 51-158 in Dynamism, Rivalry, and the Surplus Economy, edited by J. Kornai. New York: Oxford University Press.

Kotańska, Anna. 1996. "Doróżki i Dorożkarze Warszawscy w Drugiej Połowie XIX W." Rocznik Warszawski 26:129-60.

Lahire, Bernard. 2011. The Plural Actor. Cambridge, UK: Polity Press.

Leifer, Eric. 1991. Actors as Observers. New York: Garland.

Levin, Simon A. 1992. "The Problem of Pattern and Scale in Ecology." Ecology 73(6):1943-67.

Levin, Simon A., ed. 2009. The Princeton Guide to Ecology. Princeton, NJ: Princeton University Press.

Liu, Sida. 2017. "Overlapping Ecologies: Professions and Development in the Rise of Legal Services in China." Sociology of Development 3(3):212-31.

Liu, Sida, and Mustafa Emirbayer. 2016. "Field and Ecology." Sociological Theory 34(1):62-79.

Long, Norton E. 1958. "The Local Community as an Ecology of Games." American Journal of Sociology 64(3):251-61.

MacKenzie, Donald. 2016. "Capital's Geodesic: Chicago, New Jersey, and the Material Sociology of Speed." Pp. 55-72 in The Sociology of Speed, edited by J. Wajcman and N. Dodd. Oxford, UK: Oxford University Press.

Maguire, Eleanor A., David G. Gadian, Ingrid S. Johnsrude, Catriona D. Good, John Ashburner, Richard S. J. Frackowiak, and Christopher D. Frith. 2000. "Navigation-Related Structural Change in the Hippocampi of Cab Drivers." Proceedings of the National Academy of Sciences 97(8):4398-4403.

Mathew, Biju. 2008. Taxi! Cabs and Capitalism in New York City. Ithaca, NY: ILR Press.

Mazurek, Małgorzata. 2010. Społeczeństwo Kolejki. O Doświadczeniach Niedoboru 1945-1989. Warsaw, Poland: Wydawnictwo Trio.

McKenzie, Roderick Duncan. 1968. On Human Ecology. Chicago: University of Chicago Press.

Medvetz, Thomas. 2012. Think Tanks in America. Chicago: University of Chicago Press

Menger, Pierre-Michel. 2014. The Economics of Creativity. London: Harvard University Press.

Mutongi, Kenda. 2017. Matatu. Chicago: University of Chicago Press.

Occhiuto, Nicholas. 2017. "Investing in Independent Contract Work: The Significance of Schedule Control for Cab Drivers." Work and Occupations 44(3):268-95.

OECD (Organisation for Economic Co-operation and Development). 2007. "(De)Regulation of the Taxi Industry." ECMT Round Tables, No. 133. Paris: OECD Publishing. https://doi. org/10.1787/9789282101155-en.

Page, Scott E. 2015. "What Sociologists Should Know about Complexity." Annual Review of Sociology 41:21-41.

Papayanis, Nicholas. 1996. Horse-Drawn Cabs and Omnibuses in Paris. Baton Rouge: Louisiana State University Press.

Park, Robert E. 1915. "The City: Suggestions for the Investigation of Human Behavior in the City Environment." American journal of sociology 20(5):577-612. 
Park, Robert E. 1923. "The Natural History of the Newspaper." American Journal of Sociology 29(3):27389.

Park, Robert E. 1940. "News as a Form of Knowledge: A Chapter in the Sociology of Knowledge." American Journal of Sociology 45(5):669-86.

Park, Robert E. 1941. "News and the Power of the Press." American Journal of Sociology 47(1):1-11.

Park, Robert E. 1952. Human Communities. London: Free Press.

Pomian, Krzysztof. 1984. L'Ordre du Temps. Paris: Gallimard.

Pomian, Krzysztof. 1998. "Vision and Cognition." Pp. 211-13 in Picturing Science, Producing Art, edited by P. Galison and C. A. Jones. New York: Routledge.

Pomian, Krzysztof. 2013. “On Time.” Institute for Human Sciences. Retrieved May 11, 2019. http://www. iwm.at/read-listen-watch/transit-online/on-time/.

Santee, Michael. 1989. Taxidriving Made Simple: How to Do It Profitably, Pleasurably \& Professionally. Oakland, CA: Round Robin.

Schutz, Alfred. 1959. "Tiresias, or Our Knowledge of Future Events." Social Research 26(1):71-89.

Schwartz, Barry. 1974. "Waiting, Exchange, and Power: The Distribution of Time in Social Systems." American Journal of Sociology 79(4):841-70.

Sewell, William H. 2008. "The Temporalities of Capitalism.” Socio-economic Review 6(3):517-37.

Serafin, Marcin. 2016. "Cacophony of Contestation: Forms of Voice and the Warsaw Taxi Market as a Field of Struggles.” European Journal of Sociology 57(2):259-95.

Serafin, Marcin. 2017. "Weather Forecasting and the Remaking of the Chicago Tradition." European Journal of Sociology 58(3):485-92.

Sik, Endre. 1994. "The Vulture and the Calamity? Or Why Were Hungarian Taxi Drivers Able to Rebel against Increased Gasoline Prices?" Pp. 275-92 in Transition to Capitalism: The Communist Legacy in Eastern Europe, edited by J. M. Kovács. London: Transaction.

Sharma, Sarah. 2014. In the Meantime: Temporality and Cultural Politics. Durham, NC: Duke University Press. Snyder, Benjamin. 2016. The Disrupted Workplace. New York: Oxford University Press.

Tavory, Iddo. 2018. "Between Situations: Anticipation, Rhythms, and the Theory of Interaction." Sociological Theory 36(2):117-33.

Tavory, Iddo, and Nina Eliasoph. 2013. "Coordinating Futures: Toward a Theory of Anticipation." American Journal of Sociology 118(4):908-42.

Tilly, Charles. 1994. "The Time of States." Social Research 61(2):269-95.

Thompson, E. P. 1967. "Time, Work Discipline and Industrial Capitalism.” Past \& Present 38(1):56-97.

Todd, Peter M., and Gerd Gigerenzer. 2012. Ecological Rationality. New York: Oxford University Press.

Van der Zwan, Natascha. 2014. "Making Sense of Financialization." Socio-economic Review 12(1):99-129.

Veblen, Thorstein. 1898. "Why Is Economics Not an Evolutionary Science." Quarterly Journal of Economics 12(4):373-97.

Viscelli, Steve. 2016. The Big Rig: Trucking and the Decline of the American Dream. Oakland: University of California Press.

Wagner-Pacifici, R. 2017. What Is an Event? Chicago: University of Chicago Press.

White, Harrison. 1981. "Where Do Markets Come From?” American Journal of Sociology 87(3):517-47.

Winston, Gordon C. 1988. "Three Problems with the Treatment of Time in Economics." Pp. 30-52 in The Boundaries of Economics, edited by G. C. Winston and R. Teichgraeber. Cambridge, UK: Cambridge University.

Zamagni, Stefano, and Elettra Agliardi, eds. 2004. Time in Economic Theory. Vol. 1. Cheltenham, UK: Edward Elgar.

Zerubavel, Eviatar. 1981. Hidden Rhythms. Chicago: University of Chicago Press.

Zerubavel, Eviatar. 1985. The Seven Day Circle. Chicago: University of Chicago Press.

\section{AUTHOR BIOGRAPHY}

Marcin Serafin is an assistant professor and the head of the Max Planck Partner Group for the Sociology of Economic Life at the Institute of Philosophy and Sociology of the Polish Academy of Sciences. His dissertation investigated the labor practices of Warsaw taxi drivers in order to theorize the role of social time in the economy. His research interests include sociological theory, temporal order of markets, digital platforms, and human ecology. 